\title{
Food Security and Nutrition in Mozambique: Comparative Study with Bean Species Commercialised in Informal Markets
}

\author{
Alberto B. Charrua ${ }^{1,2,3}{ }^{\oplus}$, Philip J. Havik ${ }^{4}$, Salomão Bandeira ${ }^{5}$, Luís Catarino ${ }^{6}{ }^{\oplus}$, Ana Ribeiro-Barros ${ }^{7}{ }^{(1)}$, \\ Pedro Cabral ${ }^{8}{ }^{\circledR}$, Margarida Moldão ${ }^{1}$ and Maria M. Romeiras $1,6, * \mathbb{C}$
}

1 Linking Landscape, Environment, Agriculture and Food (LEAF), Instituto Superior de Agronomia (ISA) Universidade de Lisboa, Tapada da Ajuda, 1340-017 Lisbon, Portugal; albecharrua@gmail.com (A.B.C.); mmoldao@isa.utl.pt (M.M.)

2 Nova School of Business and Economics, Campus de Carcavelos, Universidade Nova de Lisboa, Rua da Holanda, n.1, 2775-405 Carcavelos, Portugal

3 Department of Earth Sciences and Environment, Faculty of Science and Technology, Licungo University, P.O. Box 2025, Beira 2100, Mozambique

4 Centre for Global Health and Tropical Medicine, Instituto de Higiene e Medicina Tropical, Universidade NOVA de Lisboa, 1349-006 Lisbon, Portugal; philip.havik@ihmt.unl.pt

5 Department of Biological Sciences, Eduardo Mondlane University, P.O. Box 257, Maputo 1100, Mozambique; salomao.bandeira@uem.mz

6 Centre for Ecology, Evolution and Environmental Changes (cE3c), Faculdade de Ciências, Campo Grande, Universidade de Lisboa, 1749-016 Lisbon, Portugal; lmcatarino@fc.ul.pt

7 Forest Research Center (CEF), Instituto Superior de Agronomia (ISA), Universidade de Lisboa, Tapada da Ajuda, 1340-017 Lisbon, Portugal; aribeiro@isa.ulisboa.pt

8 NOVA IMS, Campus de Campolide, Universidade Nova de Lisboa, 1070-312 Lisbon, Portugal; pcabral@novaims.unl.pt

Citation: Charrua, A.B.; Havik, P.J.; Bandeira, S.; Catarino, L.;

Ribeiro-Barros, A.; Cabral, P.; Moldão, M.; Romeiras, M.M. Food Security and Nutrition in Mozambique: Comparative Study with Bean Species Commercialised in Informal Markets. Sustainability 2021, 13, 8839. https://doi.org/10.3390/su13168839

Academic Editor: Roberto Mancinelli

Received: 6 July 2021

Accepted: 3 August 2021

Published: 7 August 2021

Publisher's Note: MDPI stays neutral with regard to jurisdictional claims in published maps and institutional affiliations.

Correspondence: mmromeiras@isa.ulisboa.pt

\begin{abstract}
In Mozambique (South-eastern Africa), Phaseolus vulgaris and Vigna spp. are important staple foods and a major source of dietary protein for local populations, particularly for people living in rural areas who lack the financial capacity to include meat in their daily dietary options. This study focuses on the potential for improving diets with locally produced nutritious legumes whilst increasing food security and income generation among smallholder farmers. Using bean species and varieties commercialised as dry legumes in the country, it sets out to characterize and compare the chemical properties of Phaseolus vulgaris and Vigna spp. among the most commercialised dry legume groups in Mozambique. The principal component analysis showed a clear separation between Phaseolus and Vigna species in terms of proximate composition, whereas protein content was quite uniform in both groups. It concludes that the introduction of improved cultivars of Phaseolus vulgaris and Vigna species maize-legume intercropping benefits yield, diets and increases household income with limited and low-cost inputs while enhancing the resilience of smallholder farmers in vulnerable production systems affected by recurrent drought and the supply of legumes to urban informal markets.
\end{abstract}

Keywords: East Africa; pulses; Vigna; Phaseolus; Leguminosae; malnutrition; chemical composition

\section{Introduction}

Legumes (e.g., Phaseolus vulgaris, Vigna spp., Vicia faba, Lens culinaris, Cajanus cajan, and Glycine max) have attracted great attention as a primary source of nutrients for millions of people throughout the world [1]. As the issue of nutrients (e.g., proteins) became part of the global nutrition debate since the 1940s, research into deficiencies focused on vulnerable populations in low-income countries have gained greater momentum over the last two decades. Reducing (multiple) nutrient deficiencies in children, the incidence of related conditions, and infant mortality rates, currently forms an integral part of the development agenda under the aegis of international agencies, partnerships and NGOs [2]. Promoting 
a (greater) diversity of diets and reinforcing multiple nutrient intakes by diversifying domestic food production and the supply of affordable marketable crops such as legumes constitute prime drivers of Sustainable Development Goals (SDGs) 1, 2 and 3 [3].

Of all beans of the Leguminosae family, the Vigna and Phaseolus are the best-known genera, and several species are among the most used beans in Africa, playing an important role in smallholder farmers' income generation and food security in many countries (e.g., Latin America and the Caribbean) [4,5]. Vigna subterranea and V. unguiculata are native to the African region, whereas Phaseolus vulgaris and Vigna radiata originate from Latin and Central America, and India, respectively. Currently, they are extensively cultivated all over the world [6-9]. These beans have a high nutrient value, are crucial for nutritional and food security, and reduce mal- and sub-nutrition levels in developing countries, above all in sub-Saharan Africa $[10,11]$ but also in densely populated countries such as India [12].

The consumption of dry legumes, including Vigna spp. (e.g., V. radiata or mung bean), $V$. subterranean (bambara-nut), V. unguiculata (cowpea) and several cultivars of Phaseolus vulgaris (common bean), contributes to the treatment of and has a protective effect against some degenerative chronic diseases, such as diabetes, cancer, obesity, neoplasms, and cardiovascular diseases [13-15]. Phaseolus vulgaris and Vigna spp. are important and affordable sources of vitamins, carbohydrates, minerals, energy, proteins, dietary fibres and essential amino acids for people living in developing and developed countries [11,16-18]. In Latin America and Africa (including Mozambique, see Figure 1), Phaseolus vulgaris and Vigna spp. are important staple foods and a major source of dietary protein for local populations [19], particularly for people living in rural areas who lack the financial capacity to include meat in their daily dietary options. Therefore, dry beans are also called "poor man's meat" as legume grains are rich in protein (ranging from $17 \%$ to $30 \%$ ) $[10,16,20,21]$. Belonging to the Fabaceae family, the majority of Phaseolus and Vigna species can fix atmospheric nitrogen through symbiosis with nitrogen fixing bacteria [22]. Thus, the beans are a valuable crop species for crop consociation or crop rotation and have useful components for agroforestry systems [23].

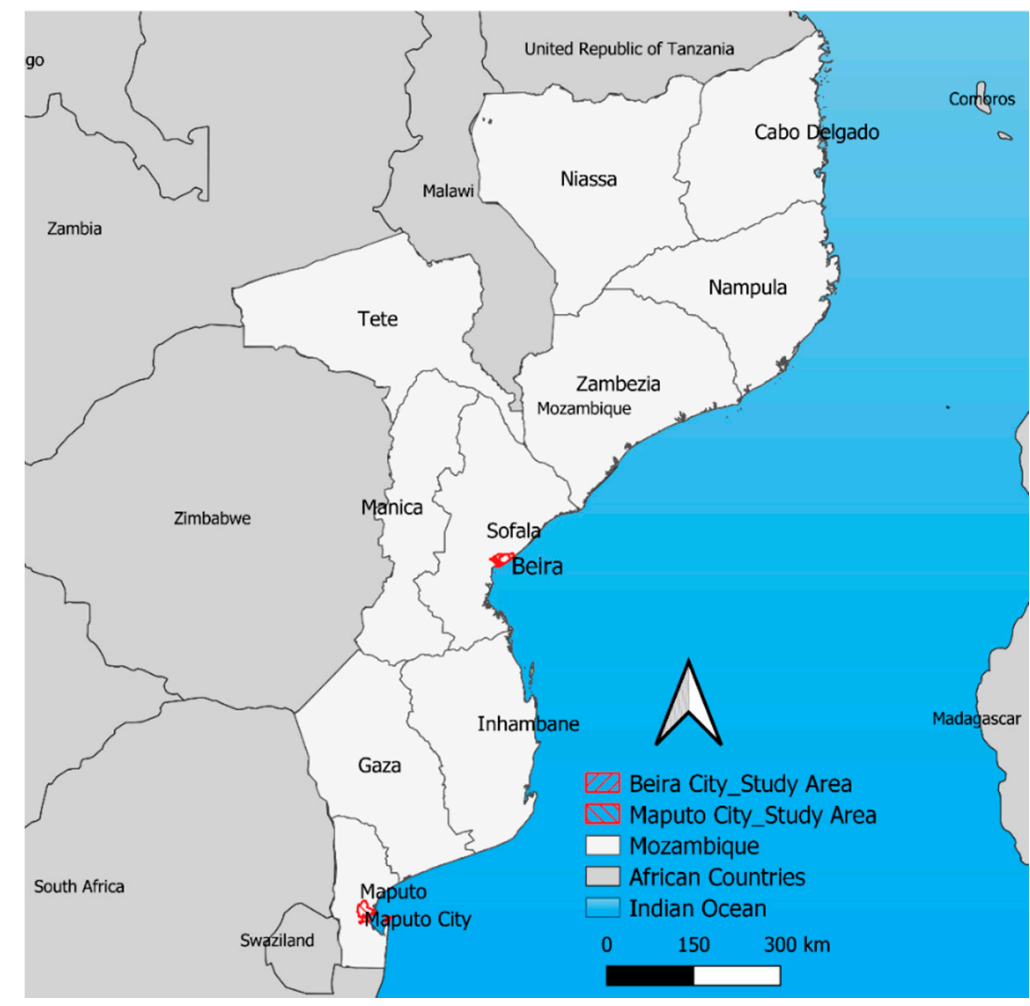

Figure 1. Geographic location of study area. 
Several Phaseolus and Vigna species comprise different varieties and/or cultivars, with distinct crop needs and organoleptic properties. For instance, Vigna species are droughttolerant crops, resistant to pests and diseases, and thrive under harsh environmental conditions [24,25]. In Mozambique, Vigna species such as V. unguiculata usually grow in smallholders' fields, home gardens, backyards and sometimes grow in the wild. Moreover, the leaves of this legume are edible, and the immature pods and seeds can also be consumed as a vegetable. The nutritional value of dry beans has been the subject of studies in several parts of the world, including the US, UK, Sultanate of Oman, China, India, Brazil, and Poland [1,20,26-29]. In Africa, the importance of pulse crops (i.e., edible seeds of plants from the Leguminosae family), including the common bean, for food and nutritional security has been recognised, as well as yield, marketing, and consumption patterns, and the key role of smallholder farming in this respect [30-33]. Regional research networks have been set up in Africa, including the East and Southern African Bean Research Network (ECABREN), to promote new technologies for seed breeding, multiplication, and delivery. Nevertheless, published research on the nutritional value of highly nutritious crops such as dry beans in Eastern and Southern African regions remains rare, and the few available studies mostly focus on South Africa [34,35].

Over the last two decades, Mozambique has been the focus of projects centring on the distribution of improved seed varieties of the common bean, as well as the cowpea, groundnut, pigeon pea, and soybean, to enhance food security among smallholder producers and on improving value chains [36,37]. In addition, the country has adopted a national multisectoral strategy to reduce food insecurity and chronic malnutrition affecting more than $40 \%$ of children aged $0-5$ years. This strategy advocates the need for improving families' access to and use of highly nutritious crops and foodstuffs [36]. Although some studies were undertaken on the common bean in Mozambique [38,39], very few studies on the laboratory characterization of the nutritional value of dry beans or their commercialisation have been published except for a summary account on the Vigna unguiculata's response to water stress and proline accumulation [40].

As far as we are aware, this is the first study addressing the nutritional value of Phaseolus vulgaris and Vigna spp. commercialised in Mozambican (in)formal markets (see Figure 2) with a focus on food security, dietary improvement, and poverty alleviation. The nutritional value of dry beans depends on a variety of factors, including genetic characteristics, regional variability, agroclimatic conditions, and postharvest processing $[1,8]$. Most of the Vigna spp. are legume varieties indigenous to sub-Saharan Africa, including Mozambique. Despite their importance as a traditional food source, these legumes are relatively underutilised and under-researched compared with the betterknown common beans [24]. Hence, Vigna spp. are considered neglected food crops [41] and were recently listed as a strategic crop in Mozambique.

This study aims to contribute to the current debate on improving diets with locally produced nutritious legumes and promoting greater food security and income generation among smallholder farmers. Using bean species and varieties of most commercialised dry legumes in Mozambique, we extracted quantitative data on the nutritional composition of Phaseolus vulgaris and Vigna spp. sold in two informal markets in Maputo and Beira cities (see Figure 2). This study also provides insights into their production, consumption, and sale based on a review of the literature and observation in loco. Specifically, we aimed to characterise and compare the chemical properties of Vigna spp. and Phaseolus vulgaris cultivars, which are among the most commercialised dry legume groups in Mozambique. 

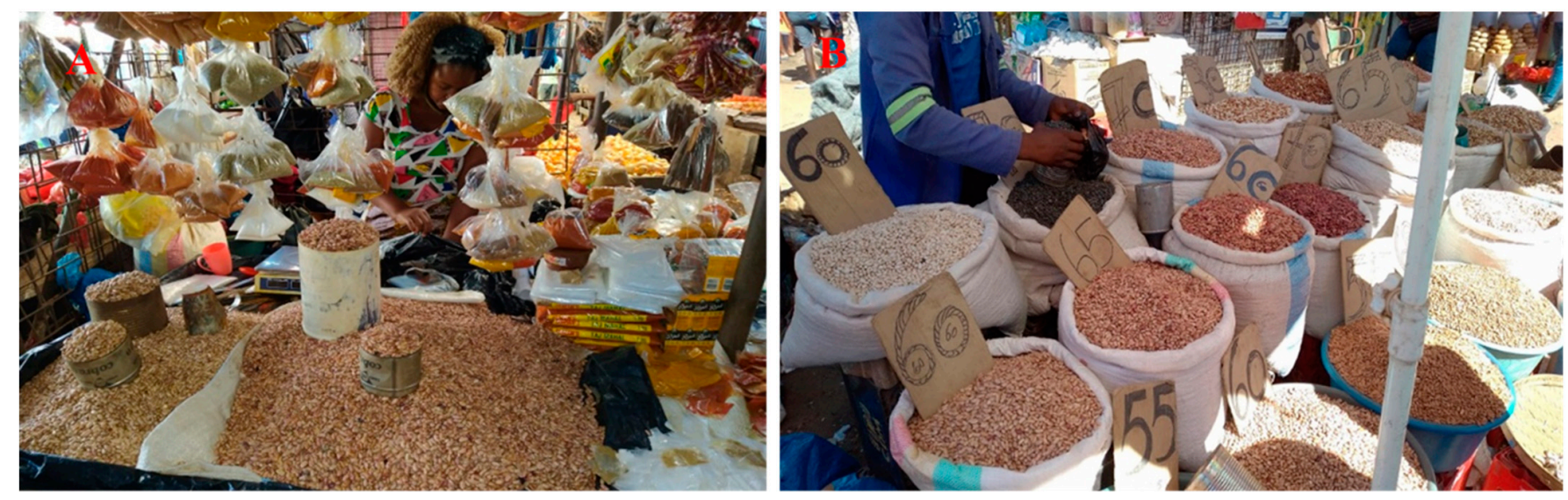

Figure 2. Informal markets in Mozambique. (A) Maquinino informal market in Beira city, and (B) Zimpeto informal market in Maputo city.

\section{Materials and Methods}

\subsection{Study Area}

Mozambique comprises a surface area of about $800,000 \mathrm{~km}^{2}$ which is divided into 11 provinces. Maputo (southern Mozambique) is the capital of the country (1.08 million inhabitants), and Beira, in Sofala province (central Mozambique), is the second largest city (552.825 inhabitants, Figure 1). According to the 2017 census [42], Mozambique's population totalled 26.99 million inhabitants (66.65\% rural population), with the Maputo and Sofala regions accounting for 2.05 and 2.22 million, respectively. Smallholder farmers produce $95 \%$ of Mozambique's agricultural output and account for almost all the beans produced, mainly cultivated by women.

Given that the markets of Maputo city and Beira are the most important in the country (Figure 2), we selected the principal markets in Beira (Maquinino informal market: Figure 2A) and Maputo city (Zimpeto informal market: Figure 2B) for the purpose of this study. Maputo and Sofala markets are located in coastal regions where beans are mostly cultivated on rainfed soils. The study areas are subjected to cyclical flooding during the rainy/monsoon season (from October to March), recurrent in the Beira region and its hinterland [43]. Beans are generally grown on poor soils, often intercropped with cereals (such as maize and sorghum), cassava, or other bean species; different varieties are planted in small quantities with relatively low yields. Harvest losses are incurred owing to pests, drought, floods, and soil degradation [44]. Together with Phaseolus lunatus (butter beans), Cajanus cajan (pigeon peas), Vigna spp. (cowpeas), Cicer arietinum (chickpeas), Vicia faba (faba beans), and Glycine max (soybeans), Phaseolus vulgaris (common beans and black beans) are a source of cheap proteins, oils, complex carbohydrates, and vitamins for vulnerable rural communities and fast-growing urban populations in the selected study areas.

\subsection{Samples and Prices}

A total of eight grains' samples of dried beans (Vigna spp. and Phaseolus vulgaris) including Vigna subterranea var. subterranea (Bambara groundnut, MP1Vs), Phaseolus vulgaris (common beans, MP2Pv), Vigna unguiculata var. tenuis (cowpea, MP4Vu), Phaseolus vulgaris (black beans, MP5Pv), Vigna radiata var. radiata (mungbean, MP6Vr), Phaseolus vulgaris (common beans, SO7Pv), Vigna unguiculata var. unguiculata (cowpea, SO12Vu), and Phaseolus vulgaris ("catarino beans or haricot catarino", SO13Pv) were purchased in the Maquinino informal market in Beira, Sofala province (Figure 2A) and Zimpeto informal market in Maputo (Figure 2B). The selection of these eight bean samples was based on their local importance, place of purchase, and difference in seed quality attributes (e.g., colour, size, and shape of seeds). The initial letters "MP" and "SO" were used as acronyms for the samples of beans acquired in Maputo and Sofala (Beira) provinces, respectively. The 
samples were previously chosen to select grains of beans free from defects and remove external material as well.

The price of each bean variety was recorded in local markets in new metical (MZN, Mozambican currency) and then converted into US dollars according to Millennium Banco Internacional de Moçambique (BIM-International Bank of Mozambique) exchange rates. The exchange rate on 23 March 2021 was: USD 1 equivalent to 71 MZN (https: / / www. millenniumbim.co.mz/pt/particulares (accessed on 23 March 2021)).

\subsection{Chemical Analysis of Proximate Composition}

Samples were analysed concerning moisture, ashes, proteins, lipids, and fatty acids (saturated, monosaturated, and polyunsaturated) and carbohydrates, dietary fibre, and energy; mostly according to the Association of Official Analytical Chemists (AOAC) and ASTM procedures. Chemical analyses were performed at the SGS Laboratory (an international and certified laboratory with global standards, https:/ / www.sgs.com/en/ certification, (accessed on 23 March 2021)), which works in partnership with the Instituto Superior de Agronomia (ISA) in Lisbon, Portugal. The moisture and ash contents were determined using a TGA701 Thermogravimetric Analyzer (LECO, EUA; Michigan) according to the ASTM D5142 standard [45]. Lipids were determined by the extraction of hexane using a Soxhlet apparatus (FOSS, soxtec 2050; Höganäs, Sweden). A Fat Extraction System (FOSS, Hillerød, Denmark) was operated according to the AOAC standards method 945.16 [46]. Fatty acids were determined by gas chromatography coupled to a flame ionization detector (GC-FID) with an Agilent 7820A Gas Chromatograph system (Agilent Technology, Santa Clara CA, USA) running GC Chemstation software (version E.02.02). The instrument was equipped with a $30 \mathrm{~m} \times 250 \mu \mathrm{m} \times 0.25 \mu \mathrm{m}$ column (Agilent Technology, USA), and experimental GC/FID setup that comprehended the following conditions of analysis: injector temperature $\left(250{ }^{\circ} \mathrm{C}\right)$, split ratio $(1: 80)$, oven temperature $\left(220^{\circ} \mathrm{C}\right)$, detector temperature $\left(270{ }^{\circ} \mathrm{C}\right)$, injection volume $(1 \mu \mathrm{L})$, and a flow rate of carrier gas (hydrogen) $(0.7 \mathrm{~mL} / \mathrm{min})$ [47]. Protein content was measured by the Dumas combustion method (analyser LECO FP-528 LC, USA) using Windows-based software FP-528 with a default protein factor of 6.25 and AOAC Method 992.23. Energy was determined according to the ASTM D5865 standard [48]. Dietary fibre was performed through VELP system using a digester dietary fibre analyser (VELP Scientifica, Italy) in accordance with AOAC Method 991.43 (and equivalent AACC Method 32-07.01) [49]. Total sugars were determined by using the Portuguese standard 1420 and the Luff-Schoorl technique [50]. Total carbohydrates were determined by the Phenol-Sulfuric Acid Method and AOAC Method 44.1.30 [51,52]. Salt content was obtained by calculation using Volhard Titration of Chloride in Plant Material (AOAC Method 915.01) [53] adapted from AOAC International [46].

\subsection{Statistical Analysis}

All dry bean data were presented as mean values. The statistical analysis was performed using the RStudio program version 1.4.1106 (The R consortium, Boston, MA, USA) [54]. Since our data did not follow a normal distribution and the variance was not homogeneous, we performed a non-parametric Kruskal-Wallis test (univariate analysis) for all variables at the 95\% confidence level. Principal component analysis (PCA) was performed based on the correlation matrix. The Kaiser criterion (eigenvalues higher than 1) was applied to explain the samples of beans projections on a two-dimensional graph (PC1 and PC2) [55]. All variables were auto-scaled prior to multivariate analysis (mean $=0$, and standard deviation $=1$ ). Cluster analysis (heatmap function) was performed to group the samples using the Ward hierarchical agglomerative method and Euclidean distance [56]. All chemical properties of samples of beans were measured in triplicate.

\section{Results}

All species are annual crops well adapted to the climate and soil conditions of Mozambique. Phaseolus vulgaris is native to Tropical America, but currently, several cultivars are 
cropped globally, whereas the three Vigna species are native to tropical Africa. Prices for dry beans in the local markets at the time of acquisition were found to range from $1.11 \mathrm{USD} / \mathrm{kg}$ (SO13 Pv) to 2.7 USD/kg (MP6 Vr), showing vast differences between both types of beans and the Maputo and Beira markets (Table 1).

Table 1. Characteristics of the bean samples analysed, from the Maputo and Beira markets, Mozambique.

\begin{tabular}{|c|c|c|c|c|}
\hline Species & $\begin{array}{c}\text { Market } \\
\text { (Accession) }\end{array}$ & Common Names & Price $(\$ / \mathbf{k g})$ & Cropping and Ecology \\
\hline Phaseolus vulgaris L. & $\begin{array}{l}\text { Maputo } \\
\text { (MP2 Pv) }\end{array}$ & $\begin{array}{l}\text { common beans } \\
\text { feijão manteiga }\end{array}$ & 1.51 & \multirow{4}{*}{$\begin{array}{l}\text { Annual twining herbs, erect. Species native to } \\
\text { tropical America, currently and extensively } \\
\text { cultivated all over the world. It grows well in } \\
\text { warm temperatures and prefers a warm sunny } \\
\text { position and well-drained soil. The roots can } \\
\text { produce a symbiotic interaction with } \\
\text { nitrogen-fixing bacteria. }\end{array}$} \\
\hline Phaseolus vulgaris L. & $\begin{array}{c}\text { Beira } \\
(\mathrm{SO} 7 \mathrm{Pv})\end{array}$ & $\begin{array}{l}\text { common beans } \\
\text { feijão manteiga }\end{array}$ & 1.39 & \\
\hline Phaseolus vulgaris L. & $\begin{array}{l}\text { Maputo } \\
\text { (MP5 Pv) }\end{array}$ & $\begin{array}{l}\text { black beans, } \\
\text { feijão-preto }\end{array}$ & 2.19 & \\
\hline Phaseolus vulgaris L. & $\begin{array}{c}\text { Beira } \\
\text { (SO13 Pv) }\end{array}$ & feijão catarino & 1.11 & \\
\hline $\begin{array}{c}\text { Vigna radiata (L.) } \\
\text { Wilczek }\end{array}$ & $\begin{array}{l}\text { Maputo } \\
\text { (MP6 Vr) }\end{array}$ & $\begin{array}{l}\text { mungbean } \\
\text { feijão soroco }\end{array}$ & 2.7 & $\begin{array}{l}\text { Annual herbs, erect, twining, or creeping. This } \\
\text { species is the main source of bean sprouts. } \\
\text { It is widely cultivated in tropical and subtropical } \\
\text { regions. It prefers a sunny environment, } \\
\text { well-drained soils rich in organic matter and } \\
\text { warm temperatures. The plant root enriches the } \\
\text { soil with nitrogen due to symbiosis with } \\
\text { nitrogen-fixing bacteria. }\end{array}$ \\
\hline $\begin{array}{l}\text { Vigna subterranea } \\
\text { (L.) Verdc. }\end{array}$ & $\begin{array}{l}\text { Maputo } \\
\text { (MP1 Vs) }\end{array}$ & $\begin{array}{c}\text { bambara groundnut } \\
\text { feijão jogo, feijão } \\
\text { ticochane }\end{array}$ & 2.04 & $\begin{array}{l}\text { Annual herb with creeping stems. Native to } \\
\text { Tropical Africa, the species is remarkably } \\
\text { drought-resistant and is an important crop in } \\
\text { semi-arid regions. It prefers sandy soils, warm } \\
\text { temperatures and can produce a symbiotic } \\
\text { interaction with nitrogen-fixing bacteria. }\end{array}$ \\
\hline $\begin{array}{l}\text { Vigna unguiculata } \\
\text { (L.) Walp. }\end{array}$ & $\begin{array}{l}\text { Maputo } \\
\text { (MP4 Vu) }\end{array}$ & $\begin{array}{l}\text { Cowpea, feijão } \\
\text { nhemba- } \\
\text { nhachengua }\end{array}$ & 1.69 & \multirow{2}{*}{$\begin{array}{l}\text { Annual or perennial herb, erect, trailing, or } \\
\text { twining, native to Tropical Africa with several } \\
\text { subspecies. It prefers a warm climate, full } \\
\text { sunlight, and tolerates a wide variety of soils so } \\
\text { long as they are well-drained. } \\
\text { This species usually engages in a symbiotic } \\
\text { relationship with nitrogen-fixing bacteria. }\end{array}$} \\
\hline $\begin{array}{l}\text { Vigna unguiculata } \\
\text { (L.) Walp. }\end{array}$ & $\begin{array}{c}\text { Beira } \\
\text { (SO12 Vu) }\end{array}$ & $\begin{array}{c}\text { Cowpea, } \\
\text { feijão-nhemba }\end{array}$ & 1.48 & \\
\hline
\end{tabular}

\subsection{Proximate Chemical Composition}

Table 2 presents the mean values for moisture content (moist.), protein (prot.), fat, saturated fatty acids (SFA), monounsaturated fatty acids (MUFA), polyunsaturated fatty acids (PUFA), total carbohydrates (TCH), energy, dietary fibre, ash content, salt, and total soluble sugars (TS). The range of values obtained for samples of beans were: from $11.8 \%$ (MP6 Vr, MP1 Vs) to 15\% (SO7 Pv) for moisture; from 17.8\% (MP1 Vs) to $24.4 \%$ (MP5 Pv) for protein; from $0.3 \mathrm{~g} / 100 \mathrm{~g}$ (SO7 Pv, SO13 Pv, MP2 Pv) to $0.8 \mathrm{~g} / 100 \mathrm{~g}$ (SO12 Vu, MP6 Vr, MP1 Vs) for SFA; from $0.2 \mathrm{~g} / 100 \mathrm{~g}$ (SO7 Pv, SO13 Pv, SO12 Vu, MP2 Pv) to $4.2 \mathrm{~g} / 100 \mathrm{~g}$ (MP1 Vs) for MUFA; from $0.5 \mathrm{~g} / 100 \mathrm{~g}$ (MP6 Vr) to $1.5 \mathrm{~g} / 100 \mathrm{~g}$ (SO7 Pv, MP2 Pv) for PUFA, from 56\% (MP5 Pv) to 61\% (MP4 Vu, MP1 Vs) for TCH; from $322 \mathrm{Kj}(\mathrm{MP} 4 \mathrm{Vu}$ ) to $1431 \mathrm{Kj}(\mathrm{MP} 1$ Vs) for energy; from 14.1\% (MP6 Vr, MP4 Vu) to 21\% (MP2 Pv) for dietary fibre; from 2.95 (SO12 Vu) to 3.55\% (SO13 Pv) for ash content; from $0.22 \mathrm{~g} / 100 \mathrm{~g}$ (SO7 Pv) to $0.48 \mathrm{~g} / 100 \mathrm{~g}$ (MP2 Pv) for salt content; and from 5.2\% (SO7 Pv) to 5.7\% (SO12 Vu) for TS. 
Table 2. Proximate analysis of dry beans.

\begin{tabular}{|c|c|c|c|c|c|c|c|c|c|c|c|c|}
\hline $\begin{array}{c}\text { Market/ } \\
\text { Accession }\end{array}$ & $\begin{array}{c}\text { Moist. } \\
(\%)\end{array}$ & $\begin{array}{l}\text { Prot. } \\
(\%)\end{array}$ & $\begin{array}{l}\text { Fat } \\
(\%)\end{array}$ & $\begin{array}{c}\text { SFA } \\
(\mathrm{g} / 100 \mathrm{~g})\end{array}$ & $\begin{array}{c}\text { MUFA } \\
(\mathrm{g} / 100 \mathrm{~g})\end{array}$ & $\begin{array}{c}\text { PUFA } \\
(\mathrm{g} / 100 \mathrm{~g})\end{array}$ & $\begin{array}{c}\mathrm{TCH} \\
(\%)\end{array}$ & $\begin{array}{c}\text { Energy } \\
(\mathrm{Kj})\end{array}$ & $\begin{array}{c}\text { Fibre } \\
(\%)\end{array}$ & $\begin{array}{c}\text { Ash } \\
(\%)\end{array}$ & $\begin{array}{c}\text { Salt } \\
\text { (g/100 g) }\end{array}$ & $\begin{array}{l}\text { TS } \\
(\%)\end{array}$ \\
\hline \multicolumn{13}{|l|}{ Maputo } \\
\hline MP1 Vs & $11.8 \mathrm{~d}$ & $17.8 \mathrm{~d}$ & $6.2 \mathrm{a}$ & $0.8 \mathrm{a}$ & $4.2 \mathrm{a}$ & $1.2 \mathrm{~cd}$ & $61 \mathrm{a}$ & 1431 a & $14.9 \mathrm{~d}$ & $3.05 \mathrm{e}$ & $0.45 c$ & \multirow{5}{*}{$\begin{array}{c}5.6 \mathrm{ab} \\
5.5 \\
\mathrm{abc} \\
5.3 \mathrm{bc} \\
5.4 \\
\mathrm{abc} \\
5.0 \\
\mathrm{abc}\end{array}$} \\
\hline MP2 Pv & $14.0 \mathrm{abc}$ & $20.5 c$ & $2.0 \mathrm{~d}$ & $0.3 \mathrm{~b}$ & $0.2 \mathrm{c}$ & $1.5 \mathrm{a}$ & $60 a b$ & $1251 \mathrm{~b}$ & $21.0 \mathrm{a}$ & $3.38 \mathrm{~b}$ & $0.48 \mathrm{~b}$ & \\
\hline MP4 Vu & $13.8 \mathrm{bc}$ & $20.1 c$ & $2.3 \mathrm{~b}$ & $0.7 \mathrm{a}$ & $0.4 \mathrm{ab}$ & $1.2 \mathrm{~cd}$ & $61 \mathrm{a}$ & $322 c$ & $14.1 \mathrm{e}$ & $3.01 \mathrm{e}$ & $0.36 \mathrm{~d}$ & \\
\hline MP5 Pv & $14.5 \mathrm{a}$ & $24.4 \mathrm{a}$ & $2.1 \mathrm{c}$ & $0.4 \mathrm{~b}$ & $0.3 \mathrm{bc}$ & $1.4 \mathrm{ab}$ & $56 \mathrm{c}$ & $1247 \mathrm{~d}$ & $20.8 \mathrm{a}$ & $3.26 \mathrm{c}$ & $0.43 c$ & \\
\hline MP6 Vr & $11.8 \mathrm{~d}$ & $23.8 \mathrm{a}$ & $1.7 \mathrm{e}$ & $0.8 \mathrm{a}$ & $0.3 \mathrm{bc}$ & $0.5 \mathrm{e}$ & $60 \mathrm{ab}$ & $1343 \mathrm{e}$ & $14.1 \mathrm{e}$ & $2.99 \mathrm{f}$ & $0.26 \mathrm{f}$ & \\
\hline \multicolumn{13}{|l|}{ Sofala } \\
\hline SO12 Vu & $13.2 \mathrm{~cd}$ & $22.0 \mathrm{~b}$ & $2.0 \mathrm{~d}$ & $0.8 \mathrm{a}$ & $0.2 \mathrm{c}$ & $1.0 \mathrm{de}$ & $60 \mathrm{ab}$ & $1305 \mathrm{f}$ & $16.9 \mathrm{c}$ & $2.95 \mathrm{~g}$ & $2.14 \mathrm{a}$ & \multirow{3}{*}{$\begin{array}{c}5.7 \mathrm{a} \\
5.5 \\
\mathrm{abc} \\
5.2 \mathrm{c}\end{array}$} \\
\hline SO13 Pv & $14.4 \mathrm{ab}$ & $21.1 \mathrm{~b}$ & $1.8 \mathrm{e}$ & $0.3 \mathrm{~b}$ & $0.2 \mathrm{c}$ & $1.3 \mathrm{bc}$ & $59 \mathrm{bc}$ & $1268 \mathrm{~g}$ & $17.1 \mathrm{~b}$ & $3.55 \mathrm{a}$ & $0.34 \mathrm{e}$ & \\
\hline SO7 Pv & $15.0 \mathrm{a}$ & $20.1 \mathrm{c}$ & $2.0 \mathrm{~d}$ & $0.3 \mathrm{~b}$ & $0.2 \mathrm{c}$ & $1.5 \mathrm{a}$ & $60 \mathrm{ab}$ & $1284 \mathrm{~h}$ & $15.3 \mathrm{~d}$ & $3.17 \mathrm{~d}$ & $0.22 \mathrm{~g}$ & \\
\hline
\end{tabular}

Values followed by different letters in the same column are significantly different (Kruskal-Wallis test, followed by Kruskal-Wallis post hoc test at $p<0.05)$.

\subsection{Principal Component Analysis (PCA)}

PCA was applied to evaluate the data of proximate composition for eight bean samples. PCA analysis showed that the first two components accounted for $75.3 \%$ (PC1-48.7\% and PC2-26.6\%) of total variance for the proximate composition (Figure 3).

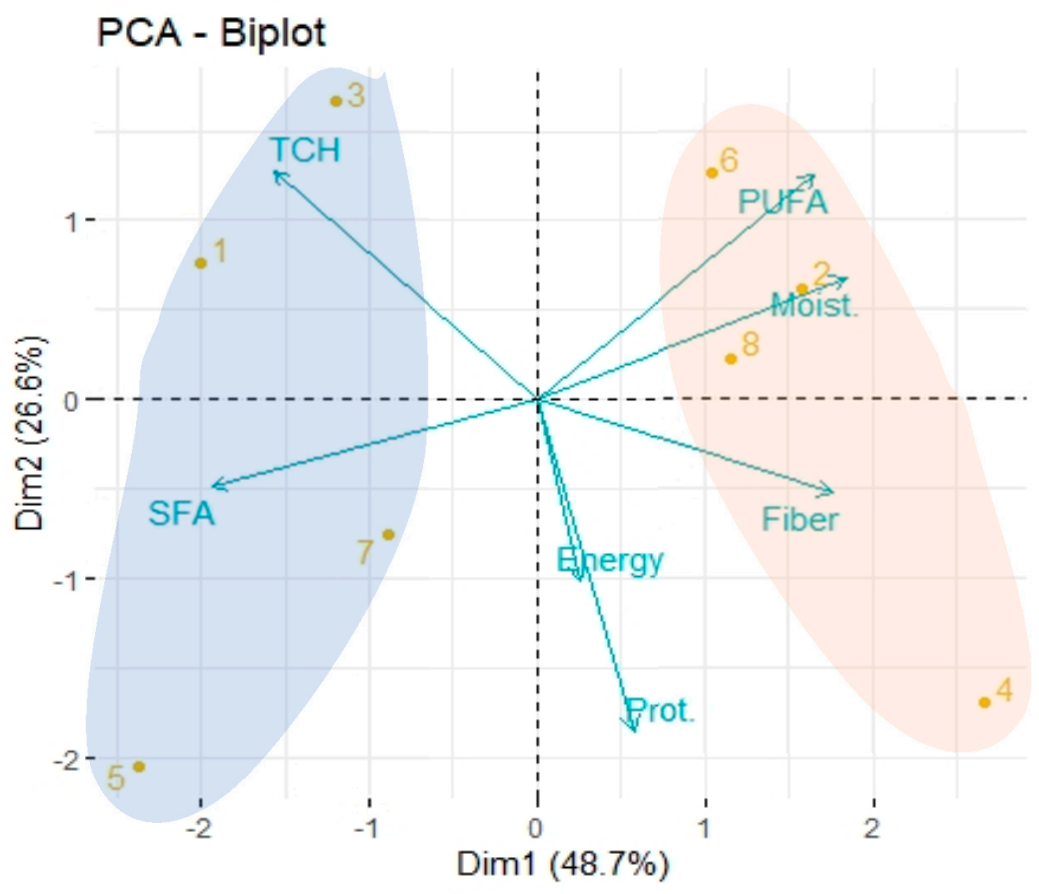

Figure 3. Biplot of the principal component analysis (PC1 and PC2) scores for eight samples of beans (proximate composition), namely: 1:MP1 Vs, 2:MP2 Pv, 3-MP4 Vu, 4:MP5 Pv, 5:MP6 Vr, 6:SO7 Pv, 7:SO12 Vu, 8:SO13 Pv.

\subsection{Cluster Analysis (CA)}

From the correlation matrix, heatmaps were constructed using the Ward hierarchical agglomerative method and Euclidean distance, where clusters of accessions are in the horizontal lines, whereas in the vertical lines are clusters of chemical characterisation data for seven proximate contents (Figure 4). The lowest values are displayed by dark violet boxes, while the highest values are represented by dark yellow boxes. The heatmap differentiates between two major groups of accessions, namely: Vigna species (Cluster 1) and Phaseolus vulgaris (Cluster 2). The proximate composition (Figure 4), moisture content, 
protein, total carbohydrates, saturated fatty acids, polyunsaturated fatty acids, energy, and dietary fibre were analysed in eight bean samples from Beira (Sofala) and Maputo in Mozambique. Cluster 1 is related to the samples of beans that presented relatively high values of total carbohydrates and saturated fatty acids, while Cluster 2 is defined by samples that contained relatively high values of fibre, polyunsaturated fatty acids, and moisture. For both groups (Clusters 1 and 2), intermediate values of energy were found in the samples.

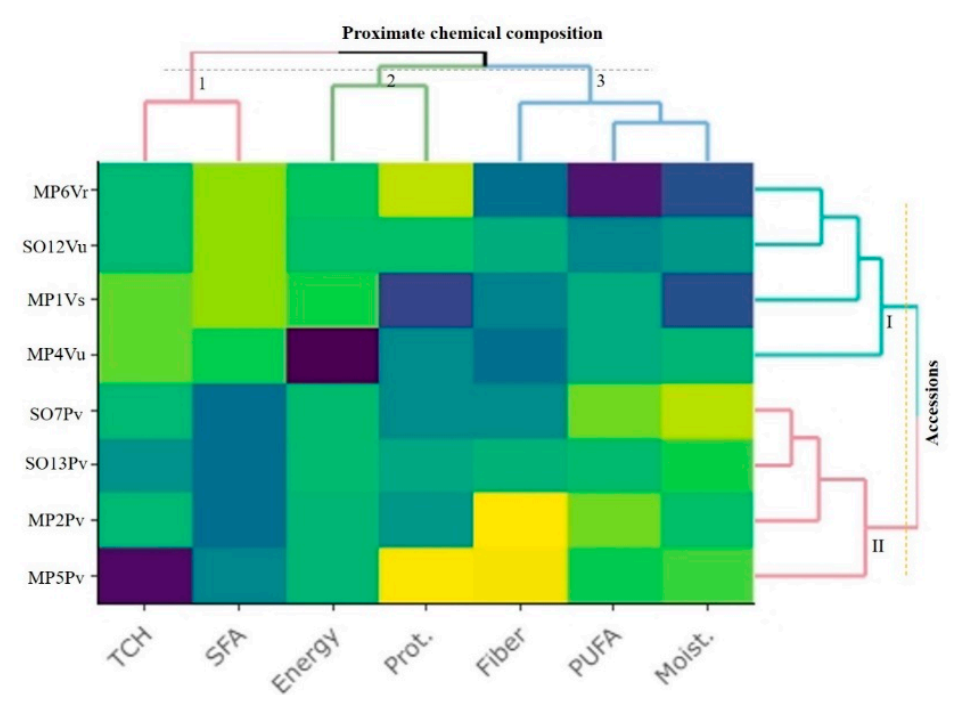

Figure 4. Heatmap of the eight accessions of dry beans (four Phaseolus vulgaris and four Vigna species) obtained from chemical characterisation data for seven proximate contents. Violet and yellow boxes indicate low values and high values, respectively.

\section{Discussion}

In Mozambique, beans are appreciated for their valuable nutritional properties, containing significant amounts of nutrients such as proteins, vitamins, and minerals [57]. Our study shows that Phaseolus and Vigna species can be distinguished from each other, namely in terms of proximate composition (see Figures 3 and 4). In line with our findings, a recent study conducted by Catarino et al. [58], using cluster analysis, showed a clear difference between Phaseolus and Vigna species in terms of mineral composition. Nevertheless, the protein content is quite uniform among the studied Phaseolus and Vigna species, but the samples from these two species collected in Maputo markets (i.e., MP5 Pv and MP6 Vr) revealed the highest protein content. These beans also attain the highest prices per kilogram in the local markets of Maputo, the capital of Mozambique. In general, these products present a high content of TCH $(>56 \%)$, with an appreciable content of fibre $(>14 \%)$ and low content of soluble sugars $(<5.7 \%)$. The lipid fraction is rich in MUFA and PUFA. The global analysis allows us to conclude that Phaseolus and Vigna species are considerably balanced foods that can contribute to decreasing food insecurity.

Phaseolus and Vigna species and pulses in general (i.e., dry beans, dry broad beans, dry peas, chickpeas, cow peas, pigeon peas, lentils, bambara beans, vetches, and lupins) also promote sustainable agriculture, providing ecological benefits by enriching the soil with their symbiotic interaction with nitrogen-fixing bacteria, and using less water than other crops [59]. Consociated cultivation, combining Vigna species and other crops such as maize and sorghum, is a common practice that enriches the soil. These species have multiple applications at the household level, through the processing and cooking of seeds, pods, and leaves to prepare foodstuffs, popular local dishes as well as being commonly used in traditional medicine.

The size and composition of smallholder farms differ as do the types of agricultural systems, cultivation techniques, and marketing options [60]. Despite efforts to quantify production and characterise agricultural systems via annual nationwide agricultural surveys, 
there is a lack of comprehensive data and understanding of smallholder bean production, consumption, and commercialisation patterns. Available survey data on smallholder farmers show that maize, cassava, and beans tend to rank among their principal crops and source of farmer households' agricultural revenue. One-fifth of smallholder farmers are under 30 , whilst $23 \%$ of smallholder households are headed by women whose inputs are critical for both crop production and marketing. The great majority $(71 \%)$ of cultivated smallholder plots are 2 ha in size or smaller. In Mozambique, the cultivated area dedicated to the production of bean species increased by approximately 50\% between 2015 and 2019 . In the provinces of Sofala and Maputo, the growth is above average $(60 \%)$ while doubling in the Maputo region over the same period [61].

Nevertheless, acute food insecurity among farmer households worsened during the same period, and markedly so in the Sofala region. Lately, the region has been affected by the impact of the strongest and most devastating tropical cyclone, Idai (category four, 2019), ever recorded in the Southern Hemisphere [62,63], and by politico-military instability in central Mozambique. Acute malnutrition levels in the Sofala region among children between 6 months and 5 years of age are among the highest in the country, significantly higher than in the Maputo region [64]. Hence, food security for already vulnerable groups practising subsistence agriculture appears to be under threat, not in the least because more than half of smallholder households live beneath the poverty line [62]. The low intake of nutrients associated with chronic malnutrition among children under five years old is regarded as a severe health and growth risk in the country [64], prompting authorities to introduce a Multisectoral Plan for Chronic Malnutrition Reduction in 2010. Legumes, and beans and peas among them, are particularly suited to alleviate malnutrition. Evaluations of food security have revealed significant stress levels, owing to low productivity, irregular precipitation, limited knowledge of food stock management, and a lack of quality and improved seeds. Nevertheless, diet adequacy in the Sofala and Maputo regions appears to be higher than the national average $[36,65]$.

Phaseolus vulgaris and Vigna spp. are the most common legumes for sale in local markets, both in Beira and Maputo, and are the most consumed and incorporated in traditional dishes. The Vigna spp. are less care-demanding and cropped in rural homesteads, while Phaseolus vulgaris is typically found in urban vegetable gardens. However, the volume of production of Vigna radiata and V. subterranea, especially the latter, is considerably smaller than that of the common bean in Mozambique. The prices were recorded at the Maputo and Beira markets, where the beans are sold in small quantities. Most consumers can probably obtain beans at lower prices from other sources (e.g., wholesale markets) or crop them in vegetable gardens, subsistence or smallholder farming. The prices fluctuate according to the seasonal cycle, being the lowest just after the harvest period when the supply is greater, and highest during the dry season, especially in the dryer areas such as the south of Mozambique.

At the time of fieldwork, a greater diversity of beans was observed in Maputo's than in Beira's markets. Vigna radiata and V. subterranea, and black beans were mostly found in Maputo, yielding higher prices. While prices per kilogram were generally higher in Maputo, the most expensive beans in the capital (black beans, mung bean, and bambara groundnut) were much less common in Beira, reflecting differences in purchasing power and consumer preferences. Higher prices are quoted for Vigna radiata and V. subterranea. Overall, the marketed beans seem to be rather expensive for local consumers and many families' budgets.

Published studies on the marketing of crops in informal markets are rare, limited to a few project reports. The Ministry of Agriculture (MINAC) implemented a price information system for several agricultural commodities (SIMA), but most smallholder farmers have difficulty accessing the information, owing to their limited access to mobile phones and networks.

For smallholders, whilst most crops are produced for domestic consumption, smaller portions are sold for cash or bartered. Hence, legume markets constitute important outlets 
for generating household income for smallholders [66]. In this respect, beans rank among the crops with the largest share of harvests destined towards revenue generation, on par with maize [62]. Despite beans' importance as a key dietary component, and their broad acceptance, market prices appear to be rather high for the purses of many Mozambicans, affecting, above all, economically vulnerable populations such as those in the study areas. Hence, priority should be given to promoting better linkage between producers and end consumers by improving the performance of (informal) marketing circuits, limiting the role of intermediaries, and enhancing understanding of consumer preferences in urban markets. As a result, producers will be able to better adapt to production on demand and thus reap greater benefits for themselves and their dependents.

Very few studies have been conducted on value chains for legumes - and beans in particular - which include informal markets [66,67]. Most smallholders sell their produce directly to their local clients and to a lesser extent via intermediaries, such as wholesale or retail agents. In terms of crop marketing, the fact that beans are the most stocked crops following maize [62], increasing farmers' stock capacity may augment income from the sale of beans in (in)formal markets [67]. However, limited smallholder household access to land, labour, funding, and income act as constraints upon the production, investment, and quality levels, whilst seasonal factors contribute to considerable price fluctuations and varying returns.

\section{Conclusions}

The smallholder production of agricultural commodities in Mozambique, which accounts for more than $95 \%$ of national output, forms the basis of populations' food security. Nevertheless, despite its importance, smallholder production of legumes, and bean species in particular, and their contribution to local diets remains under-researched and undersupported; notwithstanding the fact that Phaseolus and Vigna bean species rank among the most complete and balanced food products in terms of nutrients in Mozambican diets, constitute key ingredients in local dishes requiring relatively limited and low-cost inputs and are in great demand in accessible, informal urban markets as this study demonstrates. The introduction of improved cultivars of Phaseolus vulgaris and Vigna species would render greater yields and increase revenue from smallholder plots whilst diversifying diets with the aid of key proteins, fibres, MUFA, and PUFA. Given the existence of significant levels of sub- and malnutrition in Mozambique, including the study areas set in vulnerable farming systems, increasing the availability of beans at affordable prices would undoubtedly benefit populations', health, diet, and food security.

Author Contributions: Conceptualization, A.B.C. and M.M.R.; methodology, A.B.C. and M.M.R.; formal analysis, A.B.C. and M.M.R.; investigation, A.B.C., P.J.H. and L.C.; writing-original draft preparation, A.B.C.; writing-review and editing, A.B.C., P.J.H., S.B., L.C., A.R.-B., P.C., M.M. and M.M.R.; supervision, S.B. and M.M.R. All authors have read and agreed to the published version of the manuscript.

Funding: This research was funded by Fundação para a Ciência e Tecnologia (FCT) of the Portuguese Government by grants to A.B.C. (SFRB/BD/135360/2017). Open Access is funded by national funds through FCT I.P., in the scope of the projects Linking Landscape, Environment, Agriculture and Food Research Centre-LEAF (UIDB/04129/2020) and Centre for Ecology, Evolution and Environmental Changes-cE3c (UIDB/00329/2020).

Institutional Review Board Statement: Not applicable.

Informed Consent Statement: Not applicable.

Data Availability Statement: Not applicable.

Conflicts of Interest: The authors declare no conflict of interest. 


\section{References}

1. Ali, A.; Al-Saady, N.A.; Waly, M.I.; Bhatt, N.; Al-Subhi, A.M.; Khan, A.K. Evaluation of indigenous Omani legumes for their nutritional quality, phytochemical composition and antioxidant properties. Int. J. Postharvest Technol. Innov. 2013, 3, 333-346. [CrossRef]

2. Semba, R. The historical evolution of thought regarding multiple micronutrient nutrition. J. Nutr. 2012, 42, 143S-156S. [CrossRef]

3. Mensi, A.; Udenigwe, C.C. Emerging and practical food innovations for achieving the Sustainable Development Goals (SDG) target 2.2. Trends Food Sci. Technol. 2021, 111, 783-789. [CrossRef]

4. Takeoka, G.R.; Dao, L.T.; Full, G.H.; Wong, R.Y.; Harden, L.A.; Edwards, R.H.; Berrios, J.D.J. Characterization of Black Bean (Phaseolus vulgaris L.) Anthocyanins. J. Agric. Food Chem. 1997, 45, 3395-3400. [CrossRef]

5. Diana, L.; Carolina, G.; Ekin, B. The important role of the common beans in providing food and nutrition security. In Encyclopedia of Food Security and Sustainability; Elsevier: Amsterdam, The Netherlands, 2019; Volume 3, pp. 226-230. [CrossRef]

6. Singh, V.; Yadav, N.R.; Singh, J. Role of genomic tools for mungbean [Vigna radiata (L.) Wilczek] improvement. Legum. Res. 2017, 40, 601-608. [CrossRef]

7. Balogun, M.E.; Besong, E.E.; Obimma, J.N.; Mbamalu, O.S.; Djobissie, F.S.A. Protective roles of Vigna subterranea (Bambara nut) in rats with aspirin-induced gastric mucosal injury. J. Integr. Med. 2018, 16, 342-349. [CrossRef]

8. Gonçalves, A.; Goufo, P.; Barros, A.; Domínguez-Perles, R.; Trindade, H.; Rosa, E.A.S.; Ferreira, L.; Rodrigues, M. Cowpea (Vigna unguiculata L. Walp), a renewed multipurpose crop for a more sustainable agri-food system: Nutritional advantages and constraints. J. Sci. Food Agric. 2016, 96, 2941-2951. [CrossRef] [PubMed]

9. Graham, P.H.; Ranalli, P. Common bean (Phaseolus vulgaris L.). Field Crop. Res. 1997, 53, 131-146. [CrossRef]

10. Hayat, I.; Ahmad, A.; Masud, T.; Ahmed, A.; Bashir, S. Nutritional and Health Perspectives of Beans (Phaseolus vulgaris L.): An Overview. Crit. Rev. Food Sci. Nutr. 2014, 54, 580-592. [CrossRef] [PubMed]

11. Lin, L.-Z.; Harnly, J.M.; Pastor-Corrales, M.S.; Luthria, D.L. The polyphenolic profiles of common bean (Phaseolus vulgaris L.). Food Chem. 2008, 107, 399-410. [CrossRef]

12. Acharya, S.S. National Food Policies Impacting on Food Security: The Experience of a Large Populated Country-India. In Food Insecurity, Vulnerability and Human Rights Failure. Studies in Development Economics and Policy; Guha-Khasnobis, B., Acharya, S.S., Davis, B., Eds.; Palgrave Macmillan: London, UK, 2007; pp. 3-34, ISBN 978-0-230-58950-6. [CrossRef]

13. Jenkins, D.J.A.; Kendall, C.W.C.; Augustin, L.S.A.; Franceschi, S.; Hamidi, M.; Marchie, A.; Jenkins, A.L.; Axelsen, M. Glycemic index: Overview of implications in health and disease. Am. J. Clin. Nutr. 2002, 76. [CrossRef]

14. Englyst, N.; Hudson, G.J. The classification and measurement of dietary carbohydrates. Food Chem. 1996, 57, 15-21. [CrossRef]

15. Xu, B.J.; Yuan, S.H.; Chang, S.K.C. Comparative analyses of phenolic composition, antioxidant capacity, and color of cool season legumes and other selected food legumes. J. Food Sci. 2007, 72, 167-177. [CrossRef] [PubMed]

16. Tharanathan, R.N. Mahadevamma, S. Grain legumes-A boon to human nutrition. Trends Food Sci. Technol. 2003, 14, 507-518. [CrossRef]

17. Morrow, B. The rebirth of legumes: Legume production, consumption and export are increasing as more people become aware of legumes nutritional benefits. Food Technol. 1991, 9, 96-121.

18. Nielsen, S.S. Digestibility of legume protein: Studies indicate that the digestibility of heated legume protein is affected by the presence of other seed components and the structure of the protein. Food Technol. 1991, 45, 112-114.

19. Beebe, S.E.; Rao, I.M.; Blair, M.W.; Acosta-Gallegos, J.A. Phenotyping common beans for adaptation to drought. Front. Physiol. 2013, 4, 35. [CrossRef]

20. de Costa, G.E.A.; da Queiroz-Monici, K.S.; Reis, S.M.P.M.; de Oliveira, A.C. Chemical composition, dietary fibre and resistant starch contents of raw and cooked pea, common bean, chickpea and lentil legumes. Food Chem. 2006, 94, 327-330. [CrossRef]

21. Genovese, M.I.; Lajolo, F.M. Atividade inibitória de tripsina do feijão (Phaseolus vulgaris L.): Avaliação crítica dos métodos de determinação. Arch. Latinoam. Nutr. 2001, 51, 386-394.

22. Dakora, F.; Chimphango, S.B.M.; Valentine, A.J.; Elmerich, C.; Newton, W.E. Biological Nitrogen Fixation: Towards Poverty Alleviation through Sustainable Agriculture, 1st ed.; Springer: Amsterdam, The Netherlands, 2008; ISBN 0924-1949.

23. Atangana, A.; Khasa, D.; Chang, S.; Degrande, A. Tropical Agroforestry, 1st ed.; Springer: Amsterdam, The Netherlands, 2014; ISBN 978-94-024-0711-2.

24. Duodu, K.G.; Apea-Bah, F.B. African Legumes: Nutritional and health-promoting attributes. In Genetic and Genomic Resources of Grain Legume Improvement; Singh, M., Upadhyaya, H.D., Bisht, I.S., Eds.; Woodhead Publishing: Cambridge, UK, 2017; pp. 223-269, ISBN 9780081008911. [CrossRef]

25. Pitrat, M. Vegetable Crops in the Mediterranean Basin with an Overview of Virus Resistance. In Advances in Virus Research; Kielian, M., Mettenleiter, T.C., Roossinck, M.J., Eds.; Elsevier Inc.: New York, NY, USA, 2012; Volume 84, pp. 1-29, ISBN 9780123943149.

26. Mazur, W.M.; Duke, J.A.; Wahala, K.; Rasku, S.; Adlercreutz, H. Isoflavonoids and lignans in legumes: Nutritional and health aspects in humans. J. Nutr. Biochem. 1998, 9, 193-200. [CrossRef]

27. Shi, Z.; Yao, Y.; Zhu, Y.; Ren, G. Nutritional composition and antioxidant activity of twenty mung bean cultivars in China. Crop J. 2016, 4, 398-406. [CrossRef]

28. Mohan, V.R.; Janardhanan, K. Chemical composition and nutritional evaluation of two little-known species of Vigna. Food Chem. 1993, 48, 367-371. [CrossRef] 
29. Piecyk, M.; Wołosiak, R.; Druzynska, B.; Worobiej, E. Chemical composition and starch digestibility in flours from Polish processed legume seeds. Food Chem. 2012, 135, 1057-1064. [CrossRef]

30. Larochelle, C.; Alwang, J.; Norton, G.W.; Katungi, E.; Labarta, R.A. Impacts of improved bean varieties on poverty and food security in Uganda and Rwanda. In Crop Improvement, Adoption and Impact of Improved Varieties in Food Crops in Sub-Saharan Africa; Walker, T.S., Alwang, J.R., Eds.; CGIAR: Montpellier, France, 2015; pp. 314-337.

31. Snapp, S.; Cox, C.M.; Peter, B.G. Multipurpose legumes for smallholders in sub-Saharan Africa: Identification of promising 'scale out' options. Glob. Food Sec. 2019, 23, 22-32. [CrossRef]

32. Snapp, S.; Rahmanian, M.; Batello, C. Pulse Crops for Sustainable Farms in Sub-Saharan Africa; Calles, T., Ed.; FAO: Rome, Italy, 2018; pp. 1-60.

33. Katungi, E.; Farrow, A.; Chianu, J.; Sperling, L.; Beebe, S. Common Bean in Eastern and Southern Africa: A Situation and Outlook Analysis; International Centre for Tropical Agriculture (CIAT): Cali, Colombia, 2009; Volume 61, pp. 1-51.

34. Adebiyi, J.A.; Njobeh, P.B.; Kayitesi, E. Assessment of nutritional and phytochemical quality of Dawadawa (an African fermented condiment) produced from Bambara groundnut (Vigna subterranea). Microchem. J. 2019, 149, 104034. [CrossRef]

35. Harris, T.; Jideani, V.; Le Roes-Hill, M. Flavonoids and tannin composition of Bambara groundnut (Vigna subterranea) of Mpumalanga, South Africa. Heliyon 2018, 4, e00833. [CrossRef] [PubMed]

36. Government of Republic of Mozambique. Relatório da Avaliação da Situação de Segurança Alimentar e Nutricional; Ministério da Agricultura e Segurança Alimentar Secretariado Técnico de Segurança Alimentar e Nutricional: Maputo, Mozambique, 2017; pp. 1-19. Available online: https:/ / www.humanitarianresponse.info/sites/www.humanitarianresponse.info/files/documents / files/relatorio_avasan_marco2017_12jun2017_final_0.pdf (accessed on 7 June 2021).

37. Walker, T.; Silim, S.; Cunguara, B.; Donovan, C.; Rao, P.P.; Amane, M. Pigeonpea in Mozambique: An Emerging Success Story of Crop Expansion in Smallholder Agriculture; Ministry of Agriculture and Food Security, Directorate of Economics: Maputo, Mozambique, 2015.

38. Burridge, J.; Jochua, C.N.; Bucksch, A.; Lynch, J.P. Legume shovelomics: High-Throughput phenotyping of common bean (Phaseolus vulgaris L.) and cowpea (Vigna unguiculata subsp., unguiculata) root architecture in the field. F. Crop. Res. 2016, 192, 21-32. [CrossRef]

39. Burridge, J.D.; Findeis, J.L.; Jochua, C.N.; Miguel, M.A.; Mubichi-Kut, F.M.; Quinhentos, M.L.; Xerinda, S.A.; Lynch, J.P. A case study on the efficacy of root phenotypic selection for edaphic stress tolerance in low-input agriculture: Common bean breeding in Mozambique. F. Crop. Res. 2019, 244, 107612. [CrossRef]

40. Chiulele, R.M.; Agenbag, G.A. Plant water relations and proline accumulation on two cowpea (Vigna unguiculata L. Walp.) cultivars as a response to water stress. South Afr. J. Plant Soil 2004, 21, 109-113. [CrossRef]

41. National Research Council. Lost Crops of Africa, Volume II-Vegetables; National Academies Press: Washington, DC, USA, 2006; pp. 1-378. [CrossRef]

42. INE. IV Recenceamento Geral da População e Habitação 2017-Resultados Definitivos; Mozambique National Institute of Statistics (INE); Government of Mozambique: Maputo, Mozambique, 2019.

43. Charrua, A.B.; Bandeira, S.O.; Catarino, S.; Cabral, P.; Romeiras, M.M. Assessment of the vulnerability of coastal mangrove ecosystems in Mozambique. Ocean Coast. Manag. 2020, 189, 105145. [CrossRef]

44. Wortmann, C.R.; Kirkby, R.A.; Eledu, C.A.; Allen, D.J. Atlas of Common Bean (Phaseolus vulgaris L) Production in Africa; Centro Internacional de Agricultura Tropical (CIAT): Cali, Columbia, 1998; p. 131.

45. ASTM D5142-09. Standard Test Methods for Proximate Analysis of the Analysis Sample of Coal and Coke by Instrumental Procedures (Withdrawn 2010); ASTM International: West Conshohocken, PA, USA, 2009. Available online: https://www.astm.org/Standards/ D5142.htm (accessed on 23 March 2021).

46. Horwitz, W.; Latimer, G.W.; AOAC International. Official Methods of Analysis of AOAC International-Revision 2, 18th ed.; AOAC International: Gaithersburg, MD, USA, 2007.

47. Servent, A.; Boulanger, R.; Davrieux, F.; Pinot, M.N.; Tardan, E.; Forestier-Chiron, N.; Hue, C. Assessment of cocoa (Theobroma cacao L.) butter content and composition throughout fermentations. Food Res. Int. 2018, 107, 675-682. [CrossRef]

48. ASTM-D5865. Standard Test Method for Gross Calorific Value of Coal and Coke; ASTM International: West Conshohocken, PA, USA, 2019. Available online: https:/ / www.astm.org/Standards/D5865.htm (accessed on 7 June 2021).

49. AOAC. Official Method of Analysis: Association of Analytical Chemists, 19th ed.; AOAC: Washington, DC, USA, 2012 ; pp. 121-130.

50. NP-1420. Portuguese Standard: Determinação Dos Açúcares Totais, Dos Açúcares Redutores e Dos Açúcares Não Redutores (Sacarose). Técnica de Luff-Schoorl_Processo Corrente; Instituto Português da Qualidade: Lisboa, Portugal, 1987.

51. Nielsen, S.S. Food Analysis Laboratory Manual, 3rd. ed.; Food Science Text Series; Springer International Publishing: Cham, Switzerland, 2017; p. 264. [CrossRef]

52. Scherz, H.; Bonn, G. Analytical Chemistry of Carbohydrates; Thieme: Stuttgart, Germany, 1998; p. 354.

53. Ward, R.E.; Carpenter, C.E. Traditional Methods for Mineral Analysis. In Food Analysis, Food Science Texts Series, 4th ed.; Nielsen, S.S., Ed.; Springer Science+Business Media: New York, NY, USA, 2010; pp. 201-214.

54. RStudio Team. A single home for R and Python Data Science Teams. Available online: https://rstudio.com/products/team/ (accessed on 23 March 2021).

55. Kaiser, H.F. The application of electronic computers to factor analysis. Educ. Psychol. Meas. 1960, 20, 141-151. [CrossRef] 
56. Fan, G.; Beta, T. Discrimination of geographical origin of Napirira bean (Phaseolus vulgaris L.) based on phenolic profiles and antioxidant activity. J. Food Compos. Anal. 2017, 62, 217-222. [CrossRef]

57. Baptista, A.; Pinho, O.; Pinto, E.; Casal, S.; Mota, C.; Ferreira, I.M. Characterization of protein and fat composition of seeds from common beans (Phaseolus vulgaris L.), cowpea (Vigna unguiculata L. Walp) and bambara groundnuts (Vigna subterranea L. Verdc) from Mozambique. Food Meas. 2017, 11, 442-450. [CrossRef]

58. Catarino, S.; Brilhante, M.; Essoh, A.P.; Charrua, A.B.; Rangel, J.; Roxo, G.; Varela, E.; Moldão, M.; Ribeiro-Barros, A.; Bandeira, S.; et al. Exploring physicochemical and cytogenomic diversity of African cowpea and common bean. Sci. Rep. 2021, 11, 12838. [CrossRef] [PubMed]

59. Barbeau, C.D.; Oelbermann, M.; Karagatzides, J.D.; Tsuji, L.J.S. Sustainable agriculture and climate change: Producing potatoes (Solanum tuberosum L.) and bush beans (Phaseolus vulgaris L.) for improved food security and resilience in a Canadian subarctic first nations community. Sustainability 2015, 7, 5664-5681. [CrossRef]

60. Makate, C.; Makate, M.; Mango, N. Farm types and adoption of proven innovative practices in smallholder bean farming in Angonia district of Mozambique. Int. J. Soc. Econ. 2018, 45, 140-157. [CrossRef]

61. INE. Indicadores Básicos de Agricultura e Alimentação 2015-2019; Mozambique National Institute of Statistics (INE); Government of Mozambique: Maputo, Mozambique, 2020. Available online: http:/ /www.ine.gov.mz/estatisticas/publicacoes/indicadoresbasicos-de-agricultura-e-alimentacao-1/c-tranfer-publicacao-indicadores-basicos-de-agricultura-e-alimentacao_final.pdf/ view (accessed on 7 June 2021).

62. Anderson, J.; Learch, C. Inquérito Nacional e Segmentação de Agregados Familiares de Pequenos Produtores Agrícolas em Moçambique. Percebendo a Sua Procura por Soluções Financeiras, Agrícolas e Digitais; Consultative Group to Assist the Poorest (CGAP): Maputo, Mozambique, 2016. Available online: https://www.cgap.org/sites/default/files/publications/Mozambique\%20CGAP\%20 Smallholder\%20Household\%20Survey\%20Report_POR.pdf (accessed on 7 June 2021).

63. Charrua, A.B.; Padmanaban, R.; Cabral, P.; Bandeira, S.; Romeiras, M.M. Impacts of the tropical cyclone idai in mozambique: A multi-temporal landsat satellite imagery analysis. Remote Sens. 2021, 13, 201. [CrossRef]

64. Picolo, M.; Barros, M.J.; Gottwalt, A.; Possolo, E.; Sigauque, B.; Kavle, J.A. Rethinking integrated nutrition- health strategies to address micronutrient deficiencies in children under five in Mozambique. Matern. Child Nutr. 2019, 15. [CrossRef]

65. Government of Republic of Mozambique. Multisectoral Plan for Chronic Malnutrition Reduction 2011-2014; Government of Republic of Mozambique: Maputo, Mozambique, 2010. Available online: https:/ /www.who.int/nutrition/landscape_analysis/ MozambiqueNationalstrategyreductionstunting.pdf (accessed on 7 June 2021).

66. Chagomoka, T.; Afari-Sefab, V.; Pitoro, R. Value Chain Analysis of Traditional Vegetables from Malawi and Mozambique. Int. Food Agribus. Manag. Rev. 2014, 7, 59-86.

67. Tui, S.H.-K. Feijão Vulgar: Benefícios para os Agricultores Envolvidos Numa Produção Orientada para o Mercado; MOREP project: Maputo, Mozambique, 2015. Available online: https:/ / repo.mel.cgiar.org/handle/20.500.11766/3226 (accessed on 1 June 2021). 